\title{
Review
}

\section{Aspects of early arthritis Biological therapy in early arthritis - overtreatment or the way to go?} Kei Ikeda, Sally Cox and Paul Emery

\author{
Academic Unit of Musculoskeletal Disease, Leeds University, Chapel Allerton Hospital, Chapeltown Road, Leeds LS7 4SA, UK
}

Corresponding author: Paul Emery, p.emery@leeds.ac.uk

Published: 24 May 2007

This article is online at http://arthritis-research.com/content/9/3/211

(c) 2007 BioMed Central Ltd
Arthritis Research \& Therapy 2007, 9:211 (doi:10.1186/ar2177)

processes and the prevention of development of further inflammation [9-11]. DMARDs are currently the first line of therapy in early inflammatory disease; however, with the availability of more effective (but more expensive) agents, are we justified in now using these at the onset of disease with the realisation that initial higher costs may lead to long-term gain?

\section{Anti-tumour necrosis factor therapies}

Tumour necrosis factor- $\alpha$ (TNF- $\alpha$ ) is a potent pro-inflammatory cytokine that has a central role in the pathogenesis of RA. TNF-blocking drugs were first examined in patients with established disease [12,13]. Infliximab, a human-murine chimaeric monoclonal antibody directed against TNF- $\alpha$, was given to patients with disease refractory to traditional DMARD therapy and was found to suppress disease activity, improve the quality of life and decrease the rate of radiological progression. Control of symptoms was rapid: more than $50 \%$ achieved a $20 \%$ reduction in the number of tender and swollen joints within a fortnight (ACR20 response), and $90 \%$ achieved this within 6 weeks. A combination of infliximab and methotrexate halted joint damage in patients, unlike methotrexate alone. This study raised the question of whether early treatment may produce better outcomes than the use of TNF-blocking drugs later in the disease.

\section{Rapid clinical control}

Rapid control of disease is important for management of symptoms and maintenance of function. The ASPIRE trial evaluated the efficacy of infliximab ( $3 \mathrm{mg} / \mathrm{kg}$ or $6 \mathrm{mg} / \mathrm{kg}$ ) in combination with methotrexate versus methotrexate alone in methotrexate-naive patients with early RA [14]. Superior clinical and functional outcomes were seen at 1 year in the combination groups. No significant differences were observed in clinical efficacy between the low- and high-dose infliximab groups. More patients receiving infliximab had clinically treatment may allow the modification of underlying disease

$\mathrm{ACR}=$ American College of Rheumatology; $\mathrm{ACR} n=n \%$ reduction in number of tender and swollen joints; $\mathrm{CCP}=$ cyclic citrullinated peptide; $\mathrm{DAS} n=$ disease activity score in $n$ joints; DMARDs = disease-modifying anti-rheumatic drugs; EULAR = European League Against Rheumatism; $\mathrm{HAQ}=$ health assessment questionnaire; HACA = human anti-chimaeric antibodies; HAHA = human anti-human antibodies; MRI = magnetic resonance imaging; $\mathrm{RA}=$ rheumatoid arthritis; $\mathrm{TNF}=$ tumour necrosis factor. 
meaningful improvement in health assessment questionnaire (HAQ) scores and this was seen as early as week $2[14,15]$. Clinical remission rates at 1 year were higher in those patients receiving infliximab compared with methotrexate alone (disease activity score in 28 joints (DAS28) <2.6; $22.7 \%$ versus $14.2 \%$ ) [14,16]. Importantly, this study demonstrated that the combination of methotrexate and the TNF-blocking drug was superior to methotrexate alone in improving clinical responses and reducing disability in early disease.

The rapid response was also seen in the ERA trial, which compared two monotherapies; etanercept (10 mg or $25 \mathrm{mg}$ twice weekly) and methotrexate, in patients with early erosive disease $(<3$ years) [17]. The primary clinical endpoint was overall response during the first 6 months (measured by area under the curve for $\mathrm{ACR} n$ ). This was significantly higher in patients receiving $25 \mathrm{mg}$ of etanercept than in those receiving methotrexate monotherapy. Although patients receiving etanercept as monotherapy had a more rapid clinical response, there were no differences in the ACR20/50/70 response rates between 6 and 12 months in the methotrexate group and in patients receiving the higher dose of etanercept. However, the overall response (ACRn) was better in the etanercept group than in the patients receiving methotrexate alone.

Adalimumab, a fully humanised monoclonal antibody, was the third TNF-blocking drug to be introduced [18]. Use in combination with methotrexate in early disease showed rapid disease control and better clinical outcomes than when either was used as monotherapy. The PREMIER study [18] included 799 patients with a disease duration of less than 3 years (mean 0.7 years). A co-primary endpoint of ACR50 response was achieved in $61 \%$ of patients undergoing combination treatment, in comparison with $46 \%$ and $42 \%$ in those patients receiving monotherapy with methotrexate and adalimumab, respectively. The ACR20/50/70 responses were significantly higher at week 2 in the combination group, and this result was sustained over the 2-year trial period. DAS28 remission (a score of less than 2.6 ) was achieved by $50 \%$ of patients in the combination group, but by only $25 \%$ in the monotherapy groups.

The results of these studies show that TNF-blocking drugs, used either in combination or as monotherapy, have a more rapid clinical response than methotrexate alone in early disease [15-18]. Although anti-TNF monotherapy resulted in a better clinical response at 6 months than methotrexate monotherapy, the clinical outcomes at 12 and 24 months in those receiving a combination of TNF-blocking drugs and methotrexate were superior to the outcomes in those receiving either as monotherapy $[14,18]$.

\section{Prevention of damage}

Untreated inflammation leads to damage, and it is reasonable to predict that the earlier control achieved by TNF-blocking drugs would give superior structural outcomes. In addition to the superior clinical and functional outcomes, patients receiving combination therapy in the ASPIRE trial had superior radiological outcomes. A sub-analysis of patients with a disease duration of less than 3 years showed that combination therapy inhibited structural progression during the first 2 years of therapy [14]. In this study, the radiographic progression was defined as an increase from baseline in the van der Heijde modification of total Sharp score that was larger than the smallest detectable difference. No differences were observed in radiographic changes between the infliximab groups.

Despite the more rapid clinical improvement and better American College of Rheumatology (ACR) response status at 6 months in early ERA patients receiving etanercept, there was no significant difference in Sharp scores at 12 months between the two therapies; erosions were halted in $72 \%$ of patients receiving etanercept $(25 \mathrm{mg})$ and in $60 \%$ of those receiving methotrexate. Interestingly, an open-label extension study showed significantly lower mean changes in Sharp score and erosions in the group receiving etanercept (25 mg) at 24 months in the extension study, suggesting better efficacy of the TNF-blocking drug on long-term structural outcome [19].

The results of the PREMIER study supported those of the previous studies. The change in total Sharp score was significantly lower in the combination group, indicating significantly less radiological progression. Interestingly, although patients receiving monotherapy had equivalent clinical outcomes at 2 years, there was more radiographic damage in the group receiving methotrexate $[18,20]$. A similar finding was seen in the ATTRACT study (established disease) and ASPIRE trial, with more radiographic progression in patients receiving methotrexate monotherapy than in the combination group, irrespective of DAS28 [21] or ACR response status [22].

The findings in the PREMIER, ASPIRE and ERA studies support early aggressive intervention in RA. Importantly, the results demonstrated that a combination of methotrexate and anti-TNF is superior to methotrexate alone in preventing progressive joint destruction, improving clinical responses and reducing disability in early disease. The additional benefit of biological therapy in retarding radiographic progression may be explained by a direct effect of the antiTNF agents on osteoclasts [23-25]. In contrast, patients treated with conventional DMARDs experience structural deterioration despite clinical remission. Unpublished results (Brown AK, Conaghan PG, Karim Z, Quinn MA, Ikeda K, Peterfy CG, Hensor E, Wakefield RJ, O'Connor PJ and Emery $P$ ) suggest that subclinical inflammation detected by imaging accounts for this progression and may provide a rationale for treating these patients in apparent remission with an anti-TNF agent. 
There is no evidence that any one TNF-blocking drug has superior efficacy to the others. No comparative trials have been conducted. Practical issues, such as route of administration and patient preference, have a role in the choice of anti-TNF agent. Concurrent administration of methotrexate is required for infliximab and is advised for use with the other two agents to provide the best outcomes. Studies have suggested that patients may respond to a different anti-TNF agent if there is an inadequate response to the first [26-29]. In one study of 24 patients switched from infliximab to etanercept because of lack of efficacy, $80 \%$ achieved either a 'moderate' or 'good' European League Against Rheumatism (EULAR) response [26].

\section{Disadvantages of anti-tumour necrosis factor therapy}

Although TNF-blocking drugs have been extremely effective in improving clinical outcomes and reducing structural damage, there is the concern of the increased risk of serious infections and malignancies. TNF- $\alpha$, although an important proinflammatory cytokine, also has a role in fighting infection and in the regulation of tumour cells. With blockade of TNF- $\alpha$ comes the concern of increased susceptibility to these problems.

The results on the increased risk of serious infection during randomised trials in patients with RA have been inconsistent: some trials have shown significant association [14,30] and others no significant association [31-34]. A post-marketing surveillance and observational studies have suggested an increased risk of serious infections with anti-TNF therapies [35-37]. In a recent meta-analysis of TNF-blocking drugs (infliximab or adalimumab) in patients with RA, the threat of serious infection was $3.6 \%$, in contrast with $1.6 \%$ in controls (risk ratio of 2.01) [38]. Although the population was heterogeneous and the analysis did not control for duration of exposure in this study, it does provide a general idea of potential risk. Patients with RA, particularly those with severe disease, are at increased risk of both malignancy and infection, regardless of therapy [39-41]. In addition, patients with severe disease are also more likely to be given TNFblocking drugs, and it is therefore difficult to determine with absolute certainty the actual risk of the drug independently from the presence of disease. Rates of opportunistic infections such as tuberculosis are higher, and patients need to be screened for previous exposure before the use of TNFblocking drugs is considered. There is also concern about increased rates of malignancy, although results have been conflicting. Bongantz's meta-analysis showed that although there was an increase in skin cancers, the rate of occurrence of solid tumours was not increased compared with the general population [38]. This was in contrast with a Swedish study that did show rates of solid tumours and lymphomas to be increased in patients with RA; however, this result was independent of TNF-blocking drugs $[42,43]$. The patient population studied may be relevant to these different results. Serious infections and malignancies are rare occurrences, and rates are thought to be increased by both TNF but also by severe RA. The benefit of early control of RA may outweigh potential risks; however, the absolute risk:benefit ratio is unknown and needs to be studied further.

Development of antibodies against the drug - human antichimaeric antibodies (HACA; infliximab) or human anti-human antibodies (HAHA; etanercept/adalimumab) - is another possible problem in TNF blockade therapies. Anti-infliximab antibodies were detected in 53\%, 21\% and $7 \%$ of patients treated with infliximab as monotherapy at 1,3 and $10 \mathrm{mg} / \mathrm{kg}$, respectively [12]. Concomitant therapy with low-dose methotrexate greatly diminished the appearance of this antibody, with incidence rates of $15 \%, 7 \%$, and $0 \%$ at the three dosage levels of infliximab, which might explain the mechanism of the synergetic effect of methotrexate and infliximab shown in this study [12]. In a small study, anti-infliximab antibody developed more commonly in non-responders and in patients who had infusion reactions [44]. In a recent study with adalimumab, $17 \%$ of patients with RA developed HAHA during 28 weeks of treatment. The proportion was significantly higher in EULAR non-responders than in good responders (34\% versus 5\%) [45]. No such correlation was found for etanercept, although $5 \%$ of patients developed HACA [46].

The cost of the TNF-blocking drugs is probably the main limiting factor: they are substantially more expensive than traditional DMARDs. This direct cost of treatment needs to be balanced with the benefits of a potentially more effective treatment, preventing early job loss and yielding substantial indirect cost savings. A recent review has estimated direct costs of RA as being between 1,812 and 11,792 euros annually per patient, with indirect costs up to 3.5 -fold that amount [47]. There are several arguments about cost effectiveness. In a sub-analysis of the BeSt study, depending on the way in which productivity is valued, the costs of infliximab could be compensated for by savings in productivity [48]. Another study reviewing costs in early inflammatory disease found that a substantial proportion of the costs resulted from non-health-services costs such as travel, unpaid help from family, and work losses [49]. A recent study has shown that the combination of adalimumab and methotrexate has the ability to reduce RA-related job loss and loss of work time in patients with early RA in comparison with the use of methotrexate alone [50]. Decisions about the use of the newer biological agents must take into account both the costs of the medication and healthcare resources and also the costs to society, ranging from healthcare provision by family members to job losses.

\section{Induction of remission with anti-TNF therapy}

There has been a shift in management aims of treating rheumatoid arthritis in that we are now aiming for disease remission. If treatment-free remission were achievable by early intervention with anti-TNF therapy, it would be highly cost-effective. Preventing the development of RA before 
diagnosis would result in even more significant direct and indirect cost savings.

Quinn and colleagues conducted a double-blind randomised placebo-controlled trial of infliximab in addition to methotrexate with the aim of inducing remission in patients with RA exhibiting magnetic resonance imaging (MRI)-proven synovitis but little damage [51]. Patients with a disease duration of less than 6 months received infliximab/placebo and methotrexate every 8 weeks through to 46 weeks. The primary endpoint was synovitis as measured by MRI. At 1 year, all MRI scores were significantly better in the infliximab group, with no new erosions. In addition, a greater percentage of patients of patients in the active group achieved ACR50 and ACR70 improvement criteria seen from as early as week 14 , through to week 54 . Response was sustained in $70 \%$ of patients in the infliximab plus methotrexate group, with a median DAS28 of 2.05 (remission range) 1 year after the cessation of infliximab treatment. This was the first study to demonstrate sustained remission after a course of induction with TNF-blocking drugs. The findings were confirmed in a much larger study, BeSt [52].

The BeSt trial was a multi-centre, single-blind study in which 508 patients with less than 2 years of symptoms were randomised to one of four treatment arms: sequential monotherapy starting with methotrexate, step-up therapy from methotrexate, step-down therapy (including initial high-dose oral prednisolone) or combination methotrexate plus infliximab. Adjustments in doses were made at 3-monthly intervals with the goal of achieving a DAS44 of 2.4 or less. Endpoints were functional ability and radiographically determined damage (measured by modified Sharp/Van der Heijde score). A significantly greater and more rapid improvement in function (as measured by HAQ) was seen with the initial combination treatment and initial treatment with infliximab and methotrexate. Mean HAQ scores at 3 months were 0.6 in groups 3 and 4, compared with 1.0 in groups 1 and 2 . At 12 months there was still a clinically detectable difference between the groups ( 0.5 (groups 3 and 4 ) versus 0.7 (groups 1 and 2)). There was also significantly less radiographically determined damage than with sequential monotherapy or step-up therapy. In the group receiving infliximab, 93\% did not show radiological progression greater than the smallest detectable difference at 1 year (versus $67 \%$ and $73 \%$ in the monotherapy and step-up patients, respectively). Of patients in groups 1 to 4 , respectively $53 \%, 64 \%, 71 \%$ and $74 \%$ achieved a DAS44 of 2.4 or less at 12 months. Only the differences between group 1 and groups 3 and 4 were significant. After good control of the disease (DAS44 $\leq 2.4$ ) for at least 6 months, four patients stopped infliximab treatment; in the second year, about $50 \%$ of patients were able to stop their infliximab treatment yet remain in remission. This provided further support for the notion that the combination of a TNF-blocking drug and methotrexate was optimal in the treatment of early RA.
There are accumulating data to suggest that treating undifferentiated arithritis with corticosteroid or methotrexate could delay or prevent the development of full-blown RA. Green and colleagues demonstrated the possible reversibility of early arthritis by treatment with corticosteroid injections before diagnosis of RA [53]. The most recent study showed that patients with probable RA benefit from a 1-year course of methotrexate [54]. One could speculate that blocking TNF- $\alpha$, which is a crucial factor in the pathogenesis of RA, might be more effective in preventing disease development at a very early stage.

\section{Selecting candidates for TNF blockade therapy}

Identifying patients who benefit the most from TNF-blocking therapy is a reasonable strategy for optimising the use of these drugs. This includes determining factors for poor prognosis in patients with early RA, identifying early arthritis patients who are likely to have persistent disease and predicting responses to anti-TNF agents.

Many prognostic factors have been described for RA in several studies with radiographically determined damage or functional disability as an outcome measure. These include demographic (sex), environmental (smoking), clinical (joint count), functional (HAQ), laboratory (inflammatory markers, rheumatoid factor, anti-cyclic citrullinated peptide (antiCCP) antibody), radiographic (erosive joint damage) and genetic (shared epitope) factors; however, they vary between reports depending on the study population and the study design. Although several predicting models have been suggested with these variables, they have not been validated in different cohorts, and consensus for practical use is yet to be achieved.

Several factors have been shown to predict persistent disease and structural damage in early arthritis; these include disease duration, disease-specific autoantibodies (rheumatoid factor and anti-CCP antibody) and erosions on radiograph [55]. New imaging technology such as MRI and ultrasound have been shown to be more sensitive than physical examination for detecting synovial inflammation and more precise than conventional radiography in demonstrating bone damage, both of which may further increase the accuracy of predicting poor outcome $[56,57]$. Genetic markers may also be useful in predicting disease development and outcome. The link between HLA-DRB1 genotype (shared epitope) and RA has been validated for more than 30 years, although shared epitope is strongly associated with anti-CCP antibody and may not be an independent predictor [58]. Recently, the association in many different populations between polymorphism in PTPN22, a negative regulator of T-cell activation, and RA was reported [59]. Once an accurate prediction model is established and validated, anti-TNF therapy for 'high-risk' patients with early arthritis during a 'window of opportunity' could be justified. 
This review is part of a series on

Aspects of early arthritis

edited by Josef Smolen.

Other articles in this series can be found at

http://arthritis-research.com/articles/

review-series.asp?series=ar_Early

Even though most patients benefit from biological therapy, approximately one-quarter to one-third of patients with RA have only minor, transient clinical improvement or have no benefit from TNF-blocking therapy $[13,17]$. Considering the cost and the possible adverse event, patients who are not likely to respond should be excluded from the indication of anti-TNF therapy. So far, evidence from large cohorts is limited, and no patient/disease characteristics, genetic associations or other factors have been identified that correlate reliably with treatment outcome. Comprehensive investigations with enough power to provide reliable data are warranted.

\section{Conclusion}

The ultimate goal of treatment is to induce remission such that patients have no evidence of inflammatory disease and should ideally be in long-term drug-free remission. Although a proportion of early patients will have good responses to traditional DMARDs, TNF-blocking drugs provide more rapid control of inflammation and better long-term outcomes (in combination with methotrexate), both clinically and in terms of structural damage. Although there is as yet no clear evidence that the benefit from these new drugs outweighs the high cost and potential risks in patients with early RA, optimal use of anti-TNF therapy exclusively for high-risk patients who are likely to respond to treatment would change the cost-benefit balance substantially. Furthermore, predicting poor prognosis even before the diagnosis of RA would allow very early intervention with TNF blockades, which may enable 'prevention' in the management of RA.

\section{Competing interests}

PE has participated in clinical trials and provided expert advice for the three companies manufacturing the biological agents.

\section{References}

1. Anderson JJ, Wells G, Verhoeven AC, Felson DT: Factors predicting response to treatment in rheumatoid arthritis: the importance of disease duration. Arthritis Rheum 2000, 43:22-29.

2. Emery P: Early Arthritis. In Targeted Therapies in Rheumatology. Edited by Smolen JS, Lipsky PE. London: Martin Dunitz; 2003:509-513.

3. Mottonen $\mathrm{T}$, Hannonen $\mathrm{P}$, Korpela $\mathrm{M}$, Nissila $\mathrm{M}$, Kautiainen $\mathrm{H}$ llonen J, Laasonen L, Kaipiainen-Seppanen O, Franzen P, Helve T, et al:: Delay to institution of therapy and induction of remission using single-drug or combination-disease-modifying antirheumatic drug therapy in early rheumatoid arthritis. Arthritis Rheum 2002, 46:894-898.
4. Nell VP, Machold KP, Eberl G, Stamm TA, Uffmann M, Smolen JS: Benefit of very early referral and very early therapy with disease-modifying anti-rheumatic drugs in patients with early rheumatoid arthritis. Rheumatology (Oxford) 2004, 43:906-914.

5. van der Heide A, Jacobs JW, Bijlsma JW, Heurkens AH, van Booma-Frankfort C, van der Veen MJ, Haanen HC, Hofman DM, van Albada-Kuipers GA, ter Borg EJ, et al.: The effectiveness of early treatment with 'second-line' antirheumatic drugs. A randomized, controlled trial. Ann Intern Med 1996, 124:699-707.

6. Molenaar ET, Voskuyl AE, Dinant HJ, Bezemer PD, Boers M, Dijkmans BA: Progression of radiologic damage in patients with rheumatoid arthritis in clinical remission. Arthritis Rheum 2004, 50:36-42.

7. Pincus T, Ferraccioli G, Sokka T, Larsen A, Rau R, Kushner I, Wolfe F: Evidence from clinical trials and long-term observational studies that disease-modifying anti-rheumatic drugs slow radiographic progression in rheumatoid arthritis: updating a 1983 review. Rheumatology (Oxford) 2002, 41:13461356.

8. van der Heijde DM: Joint erosions and patients with early rheumatoid arthritis. Br J Rheumatol 1995, 34 Suppl 2:74-78.

9. Firestein GS: Pathogenesis of rheumatoid arthritis: how early is early? Arthritis Res Ther 2005, 7:157-159.

10. Quinn MA, Emery P: Window of opportunity in early rheumatoid arthritis: possibility of altering the disease process with early intervention. Clin Exp Rheumatol 2003, 21(5 Suppl 31):S154S157.

11. Raza K, Buckley CE, Salmon M, Buckley CD: Treating very early rheumatoid arthritis. Best Pract Res 2006, 20:849-863.

12. Maini RN, Breedveld FC, Kalden JR, Smolen JS, Davis D, Macfarlane JD, Antoni C, Leeb B, Elliott MJ, Woody JN, et al.: Therapeutic efficacy of multiple intravenous infusions of anti-tumor necrosis factor $\alpha$ monoclonal antibody combined with lowdose weekly methotrexate in rheumatoid arthritis. Arthritis Rheum 1998, 41:1552-1563.

13. Maini R, St Clair EW, Breedveld F, Furst D, Kalden J, Weisman M, Smolen J, Emery P, Harriman G, Feldmann M, et al.: Infliximab (chimeric anti-tumour necrosis factor alpha monoclonal antibody) versus placebo in rheumatoid arthritis patients receiving concomitant methotrexate: a randomised phase III trial. ATTRACT Study Group. Lancet 1999, 354:1932-1939.

14. St Clair EW, van der Heijde DM, Smolen JS, Maini RN, Bathon JM, Emery P, Keystone E, Schiff M, Kalden JR, Wang B, et al.: Combination of infliximab and methotrexate therapy for early rheumatoid arthritis: a randomized, controlled trial. Arthritis Rheum 2004, 50:3432-3443.

15. Smolen J, Han C, Bala M, Van der Heijde D, Emery P, Bathon JM, Keystone E, Maini RN, Kalden JR, Baker D, et al.: Patients with early rheumatoid arthritis achieved a clinically meaningful and sustained improvement in physical function after treatment with infliximab. Ann Rheum Dis 2005, 64:S418.

16. Smolen JS, Han C, Bala M, van der Heijde D, Emery $P$, Bathon JM, Keystone EC, Maini RN, Kalden JR, Aletaha D, et al.: Infliximab consistently induces clinical remission in patients with early active rheumatoid arthritis regardless of remission criteria. Arthritis Rheum 2005, 52:S139-S139.

17. Bathon JM, Martin RW, Fleischmann RM, Tesser JR, Schiff MH, Keystone EC, Genovese MC, Wasko MC, Moreland LW, Weaver $\mathrm{AL}$, et al.: A comparison of etanercept and methotrexate in patients with early rheumatoid arthritis. N Engl J Med 2000, 343:1586-1593

18. Breedveld FC, Weisman MH, Kavanaugh AF, Cohen SB, Pavelka $\mathrm{K}$, van Vollenhoven R, Sharp J, Perez JL, Spencer-Green GT: The PREMIER study: A multicenter, randomized, double-blind clinical trial of combination therapy with adalimumab plus methotrexate versus methotrexate alone or adalimumab alone in patients with early, aggressive rheumatoid arthritis who had not had previous methotrexate treatment. Arthritis Rheum 2006, 54:26-37.

19. Genovese MC, Bathon JM, Martin RW, Fleischmann RM, Tesser JR, Schiff MH, Keystone EC, Wasko MC, Moreland LW, Weaver $\mathrm{AL}$, et al.: Etanercept versus methotrexate in patients with early rheumatoid arthritis: two-year radiographic and clinical outcomes. Arthritis Rheum 2002, 46:1443-1450.

20. Emery P, Genovese MC, Kavanaugh AF, Cohen SB, Perez JL, Sasso EH: Adalimumab plus methotrexate results in less frequent and less severe radiographic progression than 
methotrexate alone at all levels of clinical response in early rheumatoid arthritis. Ann Rheum Dis 2006, 65:S88.

21. Smolen JS, Van Der Heijde DM, St Clair EW, Emery P, Bathon JM, Keystone E, Maini RN, Kalden JR, Schiff M, Baker D, et al:: Predictors of joint damage in patients with early rheumatoid arthritis treated with high-dose methotrexate with or without concomitant infliximab: results from the ASPIRE trial. Arthritis Rheum 2006, 54:702-710.

22. Smolen JS, Han C, Bala M, Maini RN, Kalden JR, van der Heijde D, Breedveld FC, Furst DE, Lipsky PE: Evidence of radiographic benefit of treatment with infliximab plus methotrexate in rheumatoid arthritis patients who had no clinical improvement: a detailed subanalysis of data from the anti-tumor necrosis factor trial in rheumatoid arthritis with concomitant therapy study. Arthritis Rheum 2005, 52:1020-1030.

23. Lam J, Takeshita S, Barker JE, Kanagawa O, Ross FP, Teitelbaum SL: TNF- $\alpha$ induces osteoclastogenesis by direct stimulation of macrophages exposed to permissive levels of RANK ligand. J Clin Invest 2000, 106:1481-1488.

24. Redlich K, Hayer S, Ricci R, David JP, Tohidast-Akrad M, Kollias G, Steiner G, Smolen JS, Wagner EF, Schett G: Osteoclasts are essential for TNF- $\alpha$-mediated joint destruction. J Clin Invest 2002, 110:1419-1427.

25. Diarra D, Stolina M, Polzer K, Zwerina J, Ominsky MS, Dwyer D, Korb A, Smolen J, Hoffmann M, Scheinecker C, et al.: Dickkopf-1 is a master regulator of joint remodeling. Nat Med 2007, 13: 156-163.

26. Buch $\mathrm{MH}$, Bingham SJ, Bejarano V, White J, Emery P: Do patients with rheumatoid arthritis demonstrate an improvement on etanercept following an inadequate response to infliximab? Arthritis Rheum 2003, 48:S325.

27. Furst D, Yocum D, Weisman M, Troum O, Bray V, Wallace D, Gaylis N, Ritter J, Yeilding N, Gilmer K: Infliximab provides additional clinical and radiographic benefits in RA patients who have an inadequate response to etanercept. Ann Rheum Dis 2005, 64:S427.

28. van Vollenhoven R, Harju A, Brannemark S, Klareskog L: Treatment with infliximab (Remicade) when etanercept (Enbrel) has failed or vice versa: data from the STURE registry showing that switching tumour necrosis factor $\alpha$ blockers can make sense. Ann Rheum Dis 2003, 62:1195-1198.

29. Burmester GR, Saez IM, Malaise MG, Kary S, Kupper H: Adalimumab (HUMIRA ${ }^{\circledR}$ ) is effective and safe in treating rheumatoid arthritis (RA) in real-life clinical practice: 1 -year-results of the ReAct study. Arthritis Rheum 2005, 52:S541-S542.

30. Keystone EC, Kavanaugh AF, Sharp JT, Tannenbaum H, Hua Y, Teoh LS, Fischkoff SA, Chartash EK: Radiographic, clinical, and functional outcomes of treatment with adalimumab (a human anti-tumor necrosis factor monoclonal antibody) in patients with active rheumatoid arthritis receiving concomitant methotrexate therapy: a randomized, placebo-controlled, 52week trial. Arthritis Rheum 2004, 50:1400-1411.

31. Furst DE, Schiff MH, Fleischmann RM, Strand V, Birbara CA, Compagnone D, Fischkoff SA, Chartash EK: Adalimumab, a fully human anti tumor necrosis factor- $\alpha$ monoclonal antibody, and concomitant standard antirheumatic therapy for the treatment of rheumatoid arthritis: results of STAR (Safety Trial of Adalimumab in Rheumatoid Arthritis). J Rheumatol 2003, 30:25632571.

32. Lipsky PE, van der Heijde DM, St Clair EW, Furst DE, Breedveld FC, Kalden JR, Smolen JS, Weisman M, Emery P, Feldmann M, et al.: Infliximab and methotrexate in the treatment of rheumatoid arthritis. Anti-Tumor Necrosis Factor Trial in Rheumatoid Arthritis with Concomitant Therapy Study Group. N Engl J Med 2000, 343:1594-1602.

33. van de Putte LB, Rau R, Breedveld FC, Kalden JR, Malaise MG, van Riel PL, Schattenkirchner M, Emery P, Burmester GR, Zeidler $\mathrm{H}$, et al:: Efficacy and safety of the fully human anti-tumour necrosis factor $\alpha$ monoclonal antibody adalimumab (D2E7) in DMARD refractory patients with rheumatoid arthritis: a 12 week, phase II study. Ann Rheum Dis 2003, 62:1168-1177.

34. Weinblatt ME, Keystone EC, Furst DE, Moreland LW, Weisman $\mathrm{MH}$, Birbara CA, Teoh LA, Fischkoff SA, Chartash EK: Adalimumab, a fully human anti-tumor necrosis factor $\alpha$ monoclonal antibody, for the treatment of rheumatoid arthritis in patients taking concomitant methotrexate: the ARMADA trial. Arthritis Rheum 2003, 48:35-45.
35. Gomez-Reino J, Carmona L, Valverde VR, Mola EM, Montero MD: Treatment of rheumatoid arthritis with tumor necrosis factor inhibitors may predispose to significant increase in tuberculosis risk: a multicenter active-surveillance report. Arthritis Rheum 2003, 48:2122-2127.

36. Kroesen S, Widmer AF, Tyndall A, Hasler P: Serious bacterial infections in patients with rheumatoid arthritis under antiTNF- $\alpha$ therapy. Rheumatology (Oxford) 2003, 42:617-621.

37. Wallis RS, Broder MS, Wong JY, Hanson ME, Beenhouwer DO: Granulomatous infectious diseases associated with tumor necrosis factor antagonists. Clin Infect Dis 2004, 38:12611265.

38. Bongartz T, Sutton AJ, Sweeting MJ, Buchan I, Matteson EL, Montori V: Anti-TNF antibody therapy in rheumatoid arthritis and the risk of serious infections and malignancies: systematic review and meta-analysis of rare harmful effects in randomized controlled trials. JAMA 2006, 295:2275-2285.

39. Erhardt CC, Mumford PA, Venables PJ, Maini RN: Factors predicting a poor life prognosis in rheumatoid arthritis: an eight year prospective study. Ann Rheum Dis 1989, 48:7-13.

40. Prior P, Symmons DP, Scott DL, Brown R, Hawkins CF: Cause of death in rheumatoid arthritis. Br J Rheumatol 1984, 23:92-99.

41. Wolfe F, Mitchell DM, Sibley JT, Fries JF, Bloch DA, Williams CA Spitz PW, Haga M, Kleinheksel SM, Cathey MA: The mortality of rheumatoid arthritis. Arthritis Rheum 1994, 37:481-494.

42. Askling J, Fored CM, Baecklund E, Brandt L, Backlin C, Ekbom A, Sundstrom C, Bertilsson L, Coster L, Geborek P, et al:: Haematopoietic malignancies in rheumatoid arthritis: lymphoma risk and characteristics after exposure to tumour necrosis factor antagonists. Ann Rheum Dis 2005, 64:14141420.

43. Askling J, Fored CM, Brandt L, Baecklund E, Bertilsson L, Feltelius N, Coster L, Geborek P, Jacobsson LT, Lindblad S, et al.: Risks of solid cancers in patients with rheumatoid arthritis and after treatment with tumour necrosis factor antagonists. Ann Rheum Dis 2005, 64:1421-1426.

44. Kapetanovic MC, Geborek P, Saxne T, Larsson L, Kristensen LE, Svenson M, Bendtzen K: Development of antibodies against infliximab during infliximab treatment in rheumatoid arthritis. Relation to infusion reactions and treatment response. Arthritis Rheum 2005, 52:S543.

45. Bartelds GM, Wijbrandts CA, Nurmohamed MT, Stapel S, Lems WF, Aarden L, Dijkmans BA, Tak P, Wolbink GJ: Clinical response to adalimumab: The relationship with anti-adalimumab antibodies and serum adalimumab concentrations in rheumatoid arthritis. Ann Rheum Dis 2007, in press.

46. Klareskog L, Wajdula J, Yeh P, Fatenejad S: Low autoantibody and anti-etanercept antibody formation and lack of impact on clinical outcomes following 5 years of treatment with Enbre ${ }^{\circledR}$ in patients with rheumatoid arthritis. Arthritis Rheum 2005, 52: S348.

47. Rat $A C$, Boissier MC: Rheumatoid arthritis: direct and indirect costs. Joint Bone Spine 2004, 71:518-524.

48. Van den Hout WB, Goekoop-Ruiterman YPM, Allaart CF, De Vries-Bouwstra JK, Van Zeben D, Hazes JMW, Kerstens P, Breedveld FC, Dijkmans BAC: Additional costs of initial therapy including infliximab (IFX) in patients with early rheumatoid arthritis (RA) may be compensated by the value of sustained working hours: 2 year results of the best study. Arthritis Rheum 2006, 54:S227-S228.

49. Cooper NJ, Mugford M, Symmons DP, Barrett EM, Scott DG: Total costs and predictors of costs in individuals with early inflammatory polyarthritis: a community-based prospective study. Rheumatology (Oxford) 2002, 41:767-774.

50. Bejarano V, Quinn M, Conaghan PG, Keenan AM, Reece RJ, Walker D, Gough AK, Emery P: Adalimumab plus methotrexate improves work stability and reduces job loss in early rheumatoid arthritis (RA): results of the prevention of work disability (PROWD) study. Arthritis Rheum 2006, 54:4037-4038.

51. Quinn MA, Conaghan PG, O'Connor PJ, Karim Z, Greenstein A, Brown A, Brown C, Fraser A, Jarret S, Emery P: Very early treatment with infliximab in addition to methotrexate in early, poor-prognosis rheumatoid arthritis reduces magnetic resonance imaging evidence of synovitis and damage, with sustained benefit after infliximab withdrawal: results from a twelve-month randomized, double-blind, placebo-controlled trial. Arthritis Rheum 2005, 52:27-35. 
52. Goekoop-Ruiterman YP, de Vries-Bouwstra JK, Allaart CF, van Zeben D, Kerstens PJ, Hazes JM, Zwinderman AH, Ronday HK, $\mathrm{Han} \mathrm{KH}$, Westedt $\mathrm{ML}$, et al.: Clinical and radiographic outcomes of four different treatment strategies in patients with early rheumatoid arthritis (the BeSt study): a randomized, controlled trial. Arthritis Rheum 2005, 52:3381-3390.

53. Green M, Marzo-Ortega H, McGonagle D, Wakefield R, Proudman S, Conaghan P, Gooi J, Emery P: Persistence of mild, early inflammatory arthritis: the importance of disease duration, rheumatoid factor, and the shared epitope. Arthritis Rheum 1999, 42:2184-2188.

54. van Dongen $\mathrm{H}$, van Aken J, Lard L, Visser K, Ronday $\mathrm{H}$, Hulsmans $\mathrm{H}$, Speyer I, Westedt M, Peeters A, Allaart $\mathrm{C}$, et al.: A doubleblind randomized clinical trial in patients with undifferentiated arthritis: the Probable rheumatoid arthritis: Methotrexate versus Placebo Treatment (the PROMPT) - study. Arthritis Rheum 2007, 56:1424-1432.

55. Visser H, le Cessie S, Vos K, Breedveld FC, Hazes JM: How to diagnose rheumatoid arthritis early: a prediction model for persistent (erosive) arthritis. Arthritis Rheum 2002, 46:357365.

56. Conaghan PG, McQueen FM, Peterfy CG, Lassere MN, Ejbjerg B, Bird P, O'Connor PJ, Haavardsholm E, Edmonds JP, Emery P, et al.: The evidence for magnetic resonance imaging as an outcome measure in proof-of-concept rheumatoid arthritis studies. J Rheumato/ 2005, 32:2465-2469.

57. Wakefield RJ, Gibbon WW, Conaghan PG, O'Connor P, McGonagle D, Pease C, Green MJ, Veale DJ, Isaacs JD, Emery P: The value of sonography in the detection of bone erosions in patients with rheumatoid arthritis: a comparison with conventional radiography. Arthritis Rheum 2000, 43:2762-2770.

58. van der Helm-van Mil AHM, Verpoort KN, Breedveld FC, Huizinga TWJ, Toes REM, de Vries RRP: The HLA-DRB1 shared epitope alleles are primarily a risk factor for anti-cyclic citrullinated peptide antibodies and are not an independent risk factor for development of rheumatoid arthritis. Arthritis Rheum 2006, 54: 1117-1121.

59. Hinks A, Worthington J, Thomson W: The association of PTPN22 with rheumatoid arthritis and juvenile idiopathic arthritis. Rheumatology (Oxford) 2006, 45:365-368. 